\title{
CHALLENGES IN MANAGING YOUR OWN CAREER DEVELOPMENT
}

\author{
Kiril Postolov ${ }^{1}$ \\ Faculty of Economics - Skopje, University Ss. "Cyril and Methodius" in \\ Skopje, Republic of North Macedonia \\ Snezana Bardarova ${ }^{2}$ \\ Faculty of Tourism and Business logistic, University "GoceDelcev" Stip, \\ Republic of North Macedonia \\ Marija Magdinceva Sopova ${ }^{3}$ \\ Faculty of Tourism and Business logistic, University "GoceDelcev" Stip, \\ Republic of North Macedonia \\ Andrijana Ristovska ${ }^{4}$ \\ Faculty of Economics - Skopje, University Ss. "Cyril and Methodius" in \\ Skopje, Republic of North Macedonia
}

\begin{abstract}
The relevance of career development and management is more prevalent in the theory and practice of the organization's functioning. Therefore, it attracts the interest of different scientific disciplines and becomes a subject of research of multiple authors. During the career development process, people are faced with a number of problems and challenges related to the work-life aspects. The work-life balance is a key factor leading to greater organizational productivity. Finding the right job is the philosophy of the process of career management. Starting from the fact that the Republic of North Macedonia faces a lack of opportunities for finding a job, or insufficient employment opportunities by profession, this paper aims to identify certain suggestions for improving it. Unless an appropriate strategy is created and no serious measures are taken, there is frustration, nepotism, brain drain from the country.
\end{abstract}

Key words: Career; Stages of career development; Work-life balance; European Employment Strategy; National Employment Strategy.

\section{INTRODUCTION}

The topic that is the subject of our research in this paper is elaborated by a number of authors and they have come up in different ways. Based on the research literature, we can see that it was the subject of research in dentistry in terms of career development of future dentists (Dhanya, et al., 2017, p. 64-70).

\footnotetext{
${ }^{1}$ kirilp@eccf.ukim.edu.mk

2 snezana.bardarova@ugd.edu.mk

3 marija.magdinceva@ugd.edu.mk

${ }^{4}$ andrijana.ristovska@eccf.ukim.edu.mk
}

Vol. 21, бpoj 1/2019, стр. 17-34 
Further research in terms of career development has been made to see the development of female managers and the implications for the success of the enterprise (Athanasopoulou, et al., 2018, pp. 1-23). Professional development and empowerment are subject to further research (Paramita, et al, 2016). Further we can see a paper by exploring the connection between career and organization in the era of a new way of achieving a career (Weng, et al, p. 3-10). And of course, this does not end with research in this issue.

It's common for everyone is that, today's society is becoming a knowledge society and human resources become a critical success factor (Micić, \& Arsić, 2017, p. 32). For these reasons, there is a text in front of you that develops some dimensions related to human resources, such as career, the balance of the profession of private life, and finding a job. Let's begin.

Modern organizations, within the functioning of the management of human resources, are increasingly concerned with the problem of career development. Modern career conceptions observe it through the prism of a factor that contributes mostly to the alignment of individual and organizational needs and interests. Creating conditions for career opportunities and development of the employees in the organization increase the quality of their work and extends their knowledge and skills. This increases and expands the competitiveness of the organization and ensures the success of all entities - the employees, the manager and the organization.

The actuality of career development and management is more present in the organizational theory and practice. Therefore, it attracts the interest of more scientific disciplines as it contributes not only to more fully utilizing the available human resources potential but also to increasing their knowledge, capabilities and skills, as well as better utilization of the acquired work experience.

A very important question that arises in the process of career development of individuals is the question of realizing a work-life balance. Work-life balance is an important topic in both professional business practice and academic research. The literature shows that worklife balance is a central issue affecting wellbeing, as family and work are the most important elements of everyone's life. Work-life balance (WLB) has become a popular research area in different fields such as sociology, psychology (e.g. Greenhaus, 2008), human resource management, organizational studies, and gender studies (e.g. Sullivan \& Smithson, 2007).

In this part, we can consider the problems of the expatriation and how to solve the balance professional and private life. 
Reasons of expatriation are: are (a) improvement of the job position; (b) better remuneration and benefits; (c) professional and communication development; (d) greater autonomy and variety of tasks; (e) the possibility of acquiring an overall perspective of the company's operations; (f) career progression; (g) status search; (h) ways of escaping personal and family problems; (i) the taste for adventure, new challenges and cultural contexts; (j) a taste for knowledge sharing and skills development (Tertuliano, et al, 2018).

One of the key barriers on the way to career development is the difficulty of finding a job, that is, a lack of employment opportunities by profession. Hence, a number of issues arise, among which: Is it a temporary or a permanent problem? What is the role of the state and its institutions in resolving it?, etc. At the very end of this paper we give an overview of the European and National Employment Strategy where the most important goals and tasks related to the sustainable employment of citizens, education and reduction of unemployment, discrimination, etc. are addressed.

\section{WHAT IS CAREER?}

Greenhaus (2008) and Schein (1987) described several themes underling different definitions of the term, including:

- The property of an occupation or organization - when used in this way, career describes the occupation itself (e.g. sales or accounting) or an employee's tenure within an organization (Dalton, et al, 1977, p.19-42);

- Advancement - career denotes one's progression and increasing success within an occupation or organization;

- Status of profession - some use the term careers to separate the "professions";

- Involvement in one's work - career is used in a negative sense to describe being extremely involved in the task or job one is doing;

- Stability of a person's work pattern - a sequence of related jobs is said to describe a career, while a sequence of unrelated jobs does not.

\section{STAGES OF CAREER DEVELOPMENT}

Career development stages are usually associated with individual human life stages. According to Greenhouse and Callahan (2010), there are five stages in the process of career development. The first one is the selection of a profession or preparation for work. Greenhouse and 
Callahan believe that this stage can last up to 25 years or may recur in people who later want to change their careers. During this stage, what is most important is to harmonize the strengths and weaknesses, values and the desired lifestyle of individuals with the demands and benefits of a range of professions. One of the problems is that there can be a lack of awareness of oneself. Other problems relate to the limitations that individuals have because of the social, cultural, and racial characteristics or gender characteristics. Another problem at this stage is the aptitude of career information that differs from those that come from family and friends. Entry into the organization is the second stage of career development. This implies that the individual finds a satisfying job that meets his qualifications and skills. Problems at this stage relate to the accuracy of the information that the organization allows, so when an individual starts to work he will realize that the reality and expectations are different. The third stage, early career is also called start and achievements. Greenhouse and Calahan (2010) believe that the period of early career lasts between 25 and 40 years. The start involves establishing and understanding "the way things are going on in the organization". Detailed programs for introduction to the workplace, feedback and support from superiors are very important. Achievements in this stage involve demonstrations of competence and gaining greater responsibilities and authority. The most important in this stage is the opportunity for having an access to career development. The fourth stage is the mature career which begins between 40 - 55 years and may involve further development and progress or retention of the existing status. In both cases, individuals send out a re-evaluation of their career and life direction. The late career is the last stage and it begins between the 50 55 years, and lasts until retirement. Calahan and Greenhouse (2010) say that workers face fewer abilities, and there are incentives for some companies to allow these individuals to work even after retirement. In contrast to the traditional beliefs that define the old people as slow and unable to learn, finds that these workers can do their job well if an organization needs them and if they are treated well. Greenhouse and Calahan (2010) also point out that flexible forms and clear standards of work, permanent decision-making and avoidance of discrimination along with the retirement arrangements for employees are very important at this stage.

\section{A CONCEPTION OF ADULT DEVELOPMENT}

Erikson (1950) proposed that people progress through eight stages during the course of their life. These stages are: 
Table 1.: Erikson's 8 Psychosocial Crisis Stages

\begin{tabular}{|c|c|c|}
\hline $\begin{array}{l}\text { Psychosocial Crisis } \\
\text { Stage }\end{array}$ & Life stage & Age Range (Years) \\
\hline 1.basic trust vs. mistrust & Infancy & $\begin{array}{l}0-1 \frac{1}{2} \text { years, baby, birth to } \\
\text { walking }\end{array}$ \\
\hline $\begin{array}{l}\text { 2.autonomy } \\
\text { and doubt }\end{array}$ & $\begin{array}{l}\text { Early } \\
\text { Childhood }\end{array}$ & $\begin{array}{l}1-3 \text { years, toddler, toilet } \\
\text { training }\end{array}$ \\
\hline 3.initiative vs. guilt & Play Age & $\begin{array}{l}\text { 3-6 years, pre-school, } \\
\text { nursery }\end{array}$ \\
\hline 4.industry vs. inferiority & School Age & 5-12 yrs, early school \\
\hline $\begin{array}{lll}\begin{array}{l}\text { 5.identity } \\
\text { confusion }\end{array} & \text { vs. } & \text { role } \\
\end{array}$ & Adolescence & 9-18 yrs, puberty, teens \\
\hline 6.intimacy vs. isolation & Young Adult & $\begin{array}{l}\text { 18-40, courting, early } \\
\text { parenthood }\end{array}$ \\
\hline $\begin{array}{l}\text { 7.generativity } \\
\text { stagnation }\end{array}$ & Adulthood & $\begin{array}{l}30-65, \text { middle age, } \\
\text { parenting }\end{array}$ \\
\hline 8.ego integrity vs. despair & Mature Age & $50+$, old age, grandparents \\
\hline
\end{tabular}

Source: https://www.businessballs.com/self-management/eriksons-psychosocial-theoryof-human-development/\#-span-wfd-id-147-eight-stages-span-

Levinsons (1978) and his colleagues developed a view of how adults develop based on the notion that adult lives progress through seasons, not unlike the seasons of the year. (According: Werner, Simone, 2009, p. 389) Levinson's four "seasonal cycles" include pre-adulthood, early adulthood, middle adulthood, and late adulthood. (Werner, Simone, 2009, p. 389) Levinson (1978) originally studied forty adult males between thirty-five and forty-five years of age. Early adulthood is entered when men begin careers and families. After an evaluation of themselves at about age thirty, men settle down and work toward career advancement. Then another transition occurs at about age forty, as men realize some of their ambitions will not be met. During middle adulthood, men deal with their particular individuality and work toward cultivating their skills and assets. Finally, the transition to late adulthood is a time to reflect upon successes and failures and enjoy the rest of life. Next, Levinson interviewed forty-five women between the ages of thirty-five and forty-five years of age. One-third was homemakers, one-third college instructors, and one-third businesswomen. In general, he found that women go through the same type of cycles that men do. However, the life stages of women tend to be tied closer to the family life cycle. 


\section{APPROACHES AND STRATEGIES FOR CAREER DEVELOPMENT}

Managing our own career development involves using a combination of different strategies. The first strategy is called "work hard and do a good job". Understanding our own work, knowing the organization, its products/services, and colleagues, is the most important part of career development. In the work, the capabilities for its proper execution are of particular importance, but also the taking of our own initiatives in terms of our ideas, our actions, interpersonal relationships and projects. It is very important to learn to work together, with open and inclusive communication and trust, making all parties well informed about the problems that arise. Making the best and most visible impacts in our organization - Strenuous work, even if it's about key goals, may not be enough. In this process, it is of particular importance to select the right people - decision makers. It is necessary to identify business needs and to focus attention only on points where a visible impact can be achieved. The reality may be that we are driven by our current role. However, managers often create a different picture, thinking that employees are happy and satisfied with what they do and work. Worse, employees may have made some mistakes recently because they no longer thought their role required their full attention. The manager can interpret mistakes as "insufficient" instead of "losing interest, because the job is overwhelming." Being a professional in everything that is done means to be a person in which people can trust and rely. Positive actions can create new opportunities; negative events can set us barriers for years. Working up - Working up is, in essence, identifying the skills and experience that are needed for the next level and actively incorporating them into our curriculum vitae. In this process, it is of utmost importance to see all the new possibilities. It is not recommended to say "no" to good opportunities, recognizing that it is usually possible to negotiate any unsatisfactory elements of roles and jobs. Employees must demonstrate their universal skills, rather than skills specialized in a particular job. Understanding Organizational Policies - Working on the system by identifying people who have the power and influence in the organization, and to find out how they can be influenced. But some are not at the top of the organization as a result of their quality. They reach the top as a result of the weaker results of their co-workers. These employees are mostly anxious people who see the world with different eyes than others in the organization. Inadequate employee management leads to barriers and defeat in the battle for success. To this end, employees need a real leader who will manage them in the overall process and work. 


\section{A COMPREHENSIVE EMPLOYEE-FOCUSED MODEL OF CAREER DEVELOPMENT}

A great deal of research has been done on the factors that affect the individual's career development. For example, Weng and McElroy (2012) tested a model of career growth, examining the relationships between career growth, occupational commitment, and turnover intentions. De Vos, et al (2011) examined the relationship between employability, competency development, and career success. Hedge and Rineer (2017) provide the foundation for developing and testing a model that captures the links between key careers constructs. Figure 1 depicts a working model of their proposed employee-centered career development and pathways framework, which illustrates how individual career-related factors, organizational factors, work-life factors, and career pathways factors interact to impact both career growth and career success. In particular, employees' ability to manage their careers is influenced not only by perceptions and behaviors associated with career performance, but also by organizational factors, such as whether they perceive the organization supports their career development, and the interplay of work and non-work factors in their lives. These factors, in combination with the characteristics of the organization's career pathways system, influence career growth and success. The key aspects of career pathways programs that are expected to have the greatest influence on employees' career development are listed below. Such programs should: require that clear criteria for advancement are developed and communicated to employees; inform training and development offerings; emphasize a collaborative employee-employer approach; undergo continual evaluation; take into account the employee's non-work demands. These career pathways program characteristics will play a critical role in translating positive organizational characteristics and individual career management factors into tangible career growth experiences. Specifically, it is expected that the key aspects of career pathways programs to moderate the relationship between positive organizational characteristics and career growth, as well as the relationship between individual career management factors and career growth. In other words, when an effective career pathways structure is in place to guide the career growth process, positive organizational factors, such as supervisor support, and individual career management strategies, such as career planning, will improve career growth for workers. 
Figure 1.: An employee-focused career pathways model

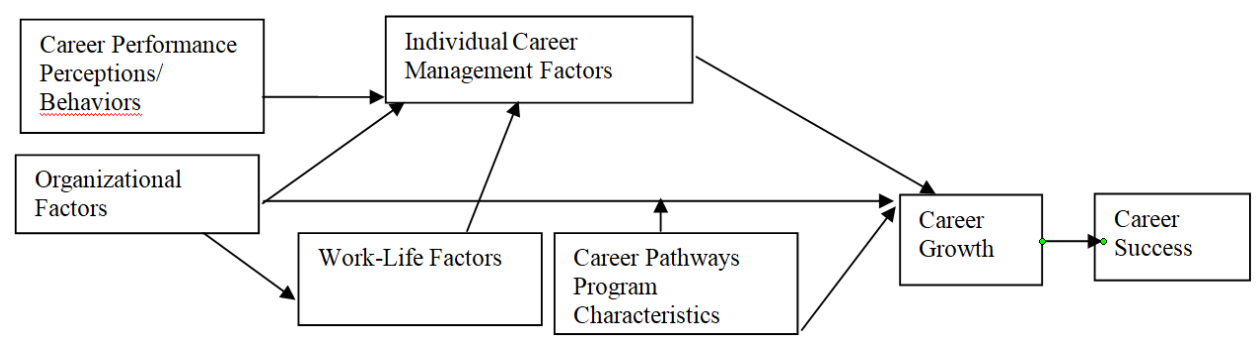

Source: Hedge \& Rineer, 2017.

\section{CAREER vs. LIFE}

We've reached a point where we need to find a useful way of thinking about the work/life balance. The challenges related to professional orientation has made it particularly difficult to make decisions and choices related to family and pursuing a professional career path (Janevska, et al, 2019, p.8). Achieving balance between life and work is an elusive ideal and considered to be a complete myth. But by making deliberate choices about which opportunities they will pursue and which they'll decline, rather than simply reacting to emergencies, leaders can and do engage meaningfully with work, family, and community (Pulevska, et al, 2017, p.3). Work-life aspects have always been a concern of those interested in the quality of working life and its relation to broader quality of life.

"Work-life balance is defined as a state of equilibrium in which the demands of both a person's job and personal life are equal" (The Word Spy, 2002). Work-life balance is founded on the idea that every person should have a complete life in which a sufficient amount of time is spent on personal interests and family interest.

A successful career requires non-traditional working hours, which can contribute to achieving a balance between work and family responsibilities.

The understanding of work-life balance brings certain results both for the individual and for the organization, at the same time enables managing the optimization between those most important aspects of life. Managing work-life balance should result in a more content loyal employee on one side and better performance results for the organization where individuals are engaged on the other.

People have to identify their priorities of life, such as: spending more time with friends and family; playing with their children; listening 
to or playing music, singing, dancing; painting, drawing, being artistic; going at the theatre or attending concerts; watching movies; relaxing; walking; religious activities; reading books; etc.

Employers can help employees achieve work-life balance by instituting policies, procedures, actions, and expectations that enable them to pursue more balanced lives, such as flexible work schedules, paid time off policies, responsibly paced time and communication expectations, and company-sponsored family events and activities. The workplace that enables employees to achieve work-life balance is particularly motivating and gratifying to employees, which makes them happy. And happy employees, whose needs for work-life balance are achieved, tend to stay with their employer and are more productive.

\section{DIFFICULTIES IN FINDING A JOB}

Each individual strives to create a successful career, but there are numerous barriers that make this process difficult. The most significant and most serious problem that arises is related to finding a job. But how and why? Is this problem temporary or permanent? What is the role of the State and its institutions for balancing it? What State Employment Strategy is necessary?

Unless an appropriate strategy is created and no serious measures are taken, there is frustration, nepotism, brain drain from the country. In this context, and starting from the seriousness of this issue and the fact that the Republic of North Macedonia faces a high level of dissatisfaction on the basis of this issue, this paper presents the European Employment Strategy, as well as the National Employment Strategy that will serve as a basis for comparing and diagnosing the problem, as well as identifying certain suggestions for improving it.

\subsection{European Employment Strategy}

The European employment strategy (EES) dates back to 1997, when the EU Member States undertook to establish a set of common objectives and targets for employment policy. Its main aim is the creation of more and better jobs throughout the EU. The European Employment Strategy (EES) is a key pillar of risk management at the European level. It was first introduced to cope with the risk of unemployment, and extended later to the risk of non-employment, with an increasing focus on activation and the need for maximising the employment rate of the working age population. (Erhel, Gautie, Gazier, 2015)

Vol. 21, бpoj 1/2019, cmp. 17-34 
In 2010, given the impact of the economic crisis, the Commission proposed the Europe 2020 strategy for smart, sustainable and inclusive growth as a way to overcome the structural weaknesses in Europe's economy, improve its competitiveness and productivity, reduce the unemployment and underpin a sustainable social market economy (Europe Commision, European Employment Strategy, 2010) . Its most significant targets are given in the following:

- Developing a coordinated strategy for employment and particularly for promoting a skilled, trained and adaptable workforce and labour markets responsive to economic change with a view to achieving the objectives of full employment and social progress. They aim to achieve 75\% of people aged 20-64 to be in work.

- Fight against social exclusion and discrimination, promote social justice and guarantee of adequate social protection, as well as equality between women and men.

- Promotion of a high level of employment, education and training.

- Increase the rate of employment, improve the process of education and poverty reduction.

- Reforms to the labour market (including the national wage-setting mechanisms) should follow national practices of social dialogue and allow the necessary policy space for a broad consideration of socioeconomic issues.

- Building a cohesive society in which people are empowered to anticipate and manage change, and can actively participate in society and the economy.

- Ensuring an effective functioning of labour markets and social protection systems and removing barriers to labour-market participation (Member States should also make sure that the benefits of economic growth reach all citizens and all regions).

In order to realize the set targets, the Member States of the European Union are required to undertake the following activities:

- Facilitate the creation of quality jobs, reduce the barriers business faces in hiring people, promote entrepreneurship and, in particular, support the creation and growth of small enterprises, promote the social economy and foster social innovation.

- Reductions in labour taxation should aim to remove barriers and disincentives in relation to participation in the labour market, in particular for those furthest away from the labour market.

- Member States should, together with social partners and in line with national practices, encourage wage-setting mechanisms allowing for a responsiveness of wages to productivity 
developments. Differences in skills and divergences in economic performance across regions, sectors and companies should be taken into account. When setting minimum wages, Member States and social partners should consider their impact on in-work poverty, job creation and competitiveness.

- Promote productivity and employability through an appropriate supply of relevant knowledge, skills and competences. Member States should make the necessary investment in all education and training systems in order to improve their effectiveness and efficiency in raising the skill and competences of the workforce, thereby allowing them to better anticipate and meet the rapidly changing needs of dynamic labour markets in an increasingly digital economy and in the context of technological, environmental and demographic change. Member States should step up efforts to improve access for all to quality lifelong learning and implement active-ageing strategies that enable longer working lives.

- Structural weaknesses in education and training systems should be addressed to ensure quality learning outcomes and reduce the number of young people leaving school early (one of the targets is to achieve rates of early school leavers below 10\%, at least $40 \%$ of people aged 30-34 to have completed higher education). Member States should increase educational attainment, encourage work-based learning systems such as dual learning, upgrade professional training and increase opportunities for recognising and validating skills and competences acquired outside formal education.

- High unemployment and inactivity should be tackled. Long-term and structural unemployment should be significantly reduced and prevented by means of comprehensive and mutually reinforcing strategies that include individualised active support for a return to the labour market. Youth unemployment and the high number of young people not in education, employment or training (NEETs), should be comprehensively addressed through a structural improvement in the school-to-work transition, including through the full implementation of the Youth Guarantee.

- Barriers to employment should be reduced, especially for disadvantaged groups. Female participation in the labour market should be increased and gender equality must be ensured, including through equal pay. The reconciliation between work and family life should be promoted, in particular access to affordable 
quality early childhood education, care services and long-term care.

- Member States should make full use of the European Social Fund and other Union funds to foster employment, social inclusion, lifelong learning and education and to improve public administration.

- Member States should take into account the flexibility and security principles ('flexicurity principles'). They should reduce and prevent segmentation within labour markets and fight undeclared work. Quality employment should be ensured in terms of socioeconomic security, work organisation, education and training opportunities, working conditions (including health and safety) and work-life balance.

- Involve national parliaments and social partners in the design and implementation of relevant reforms and policies.

- Member States should aim for better, more effective public employment services to reduce and shorten unemployment by providing tailored services to support jobseekers, supporting labour-market demand and implementing performancemeasurement systems.

- Member States should effectively activate and enable those who can participate in the labour market to do so, while protecting those unable to participate. Member States should promote inclusive labour markets open to all women and men, putting in place effective anti-discrimination measures, and increase employability by investing in human capital.

- The mobility of workers should be promoted with the aim of exploiting the full potential of the European labour market. Mobility barriers in occupational pensions and in the recognition of qualifications should be removed. Member States should at the same time prevent abuses of the existing rules and recognise potential 'brain drain' from certain regions.

- Modernise social protection systems to provide effective, efficient and adequate protection throughout all stages of an individual's life, fostering social inclusion, promoting equal opportunities, including for women and men, and addressing inequalities. Particular attention should also be given to basic services and actions to prevent early school leaving, reduce in-work poverty and fight poverty and social exclusion. Social protection systems should be designed in a way that facilitates take-up for all those entitled to do so, supports protection and investment in human capital, and helps to prevent, reduce and protect against poverty 
(at least 20 million fewer people in or at risk of poverty/social exclusion) and social exclusion through the life cycle.

- Secure the sustainability and adequacy of pension systems for women and men and improve the quality, accessibility, efficiency and effectiveness of health and long-term care systems, while safeguarding sustainability.

\subsection{Employment Strategy in the Republic of North Macedonia}

National Strategy of Employment in the Republic of North Macedonia is a document which covers mid-term strategies of employment. It includes the main challenges of the labour market in the period 2016-2020 according to the aspects of macroeconomic and microeconomic politics, politics of employment and politics of labour market, politics of social insurance and social protection. This strategy is performed in order to analyze the labour market through time and its current state, the future planned politics and the programme of Macedonian Government for the period 2016-2020.

In 2014 , the employment rate for the population aged 15-64 is $47 \%$. In the period between 2009-2014, the employment rate increased for $8 \%$ or 3.6 percentage points. However, it remains at a low level and indicates a lack of utilization of the workforce as a development potential (Ministry of labour and social politics, National Strategy of Employment, 2016-2020).

The employment rate among young people is low: only $15 \%$ of young people aged 15-24 are employed. One of the reasons is the low activity of young people, which mainly stems from participation in the education system. Employment rates are progressively increasing with an increase in the level of education. Thus, in 2014, young people with higher education have an employment rate of $69 \%$, those with secondary education - $52.5 \%$ and those with low education - 30\%. In the period 2009-2014, the employment rate increased mostly among the people with primary education (almost 10\%). These changes in the employment rate according to educational levels are the result of the movements and the supply and demand side of the workforce.

The Republic of North Macedonia faces an unemployment rate that is continuously declining. The unemployment rate in 2014 was $28 \%$ (from $32.3 \%$ in 2009). Unemployment almost equally affects both females and males.

The key challenges in the Republic of North Macedonia that refer to employment, living standards and productivity are divided into six categories: the macroeconomic framework; labor market; employment 
policy; education, training and human capital; business environment and competitiveness and vulnerable categories. The challenges facing the labor market, the challenges arising from the employment policy, as well as those of education are presented below.

Low employment rate; structural unemployment; gender gap in employment; as well as the problem of youth employment, along with the long transition period from their education to the labor market, are part of the main challenges, but also the problems that our society faces and for which it is necessary to seriously engage and take long-term measures. Another serious challenge is the intensive growth of the supply of highly educated people followed by the possible increase in unemployment leading to the phenomenon of over-education.

The employment policy in our country is most often neglected and followed by a lack of long-term planning, because of the belief that macroeconomic stability will affect employment growth. Trainings are not enough to solve all problems related to inadequate education. Therefore, measures are needed to improve the skills, qualification, acquiring internship experience and increasing the level of information for the needs of the companies. One of the main challenges in this area is the increase in financing and strengthening the role of the Employment Agency of the Republic of North Macedonia, that is, its role as a mediator in the employment process. Other employment policy challenges relate to strengthening social dialogue, as well as bringing the wage growth rate closer to the rate of productivity growth.

In terms of education, training and human capital, national measures and policies are geared towards greater utilization of human capital; improving educational indicators; structurally adjusting educational programs to economic needs and, consequently, improving the manner and quality of collecting detailed information; promotion of systems for validation and functioning of non-formal and informal learning, as well as adult and lifelong learning programs. Also, it is necessary to increase the inclusion rate of employers in the reforms of the creation of labor force according to their needs by investing in the training of new workers at the workplace. Regarding the needs of employers, education plays a particularly important role and it is necessary to contribute to responding to those needs.

The issue of gender employment gap is a complex spiral of discrimination which is still a complex issue in our society. Women (especially those with lower levels of education) are a very vulnerable category in the labor market. There is still a division and stereotypes about "male" and "female" occupations in the society (the gap is estimated at $17 \%)$. 
Young people, as well as beneficiaries of social financial assistance (mostly those with lower education), have recently begun efforts for their greater activation and participation in active employment measures. Another serious problem is the long-term unemployment of the unemployed (about 80\%, among which the most represented are those who are unemployed for more than 3 years, who have very little chance of finding a job, or who work in the informal economy).

The main goal of the National Employment Strategy of the Republic of North Macedonia 2020 is "Increasing employment, job quality and productivity, with a special focus on vulnerable population groups". This goal can be achieved by increasing the effectiveness and efficiency of the employment policy, with special support for vulnerable population categories; improving the capacity of the private sector to create jobs and to strengthen education in order to produce knowledge and skills according to the needs of employers.

\section{CONCLUSION}

Career is the factor that contributes most to linking individual and organizational needs and interests. With career development, employees and managers with appropriate abilities and appropriate experience can increase the competitiveness of the organization and the ability to adapt to the environmental changes.

In today's competitive society, work/life balance is considered important by many. A successful career requires non-traditional working hours, which can contribute to achieving a balance between work and family responsibilities. The understanding of work-life balance brings certain results both for the individual and for the organization, at the same time enables managing the optimization between those most important aspects of life. Managing work-life balance should result in a more content loyal employee on one side and better performance results for the organization where individuals are engaged on the other.

When talking about individual career choices, there are four general individual characteristics that influence the choice. First, interests, where people tend to lead a career that they believe fit their interests. The next characteristic is the image of one person which could be explained by the fact that people follow careers in which they can "see" themselves. The third dimension is the character of an employee which includes his or her orientation and personal needs. However, the problem faced by a number of societies, which is related to the difficulties in finding a job reduces the impact of these characteristics. In order to overcome the structural weaknesses in Europe's economy, improve its competitiveness

Vol. 21, бpoj 1/2019, cmp. 17-34 
and productivity, reduce the unemployment and underpin a sustainable social market economy, the European Commission proposed the European 2020 Employment Strategy.

As a country that is preparing to join the European Union, Republic of North Macedonia faces a severe lack of opportunities for finding a job, or insufficient employment opportunities by profession. The main goal of the National Employment Strategy of the Republic of North Macedonia 2020 is "Increasing employment, job quality and productivity, with a special focus on vulnerable population groups". This goal can be achieved by increasing the effectiveness and efficiency of the employment policy, with special support for vulnerable population categories; improving the capacity of the private sector to create jobs and to strengthen education in order to produce knowledge and skills according to the needs of employers. But, the employment policy in our country is most often neglected and followed by a lack of long-term planning, because of the belief that macroeconomic stability will affect employment growth.

With its entry into the EU, our country should recognize and intensify its steps towards European employment practices, policies and strategies. The government's measures to reduce inefficiency have shown successful results, but what we need is to have real employments based on appropriate competencies, knowledge and skills. It is necessary to overcome many social injustices, illusions and nepotism, to put in place the practice of a right man in the right place, with valued results of labor, with the established career development system.

The first step towards the European employment system is stabilization and proper targeting of reform educational processes, higher quality of workforce, greater opportunities for mobility and re-training depending on the momentary need of the labor market. The quality of practical training and improvement of the quality of the labor market is one of the most important priorities in the Republic of Macedonia. For these reasons, secondary vocational education is in continuous reforms oriented towards increasing the number of hours for practical training, equipping school workshops, training teachers, but in recent years, the focus has been on strengthening the links between schools and companies for the realization of WBL (Work-Based Learning) in real working conditions.

To create opportunities for quick new qualifications in an informal and informative way through adult education based on the principle of lifelong learning in the direction of fast employment and career advancement is of particular importance. In order for education to achieve quality of qualifications, it is necessary to have proper functioning of 
career centers that will monitor the interests and abilities of young people from the youngest age and will properly direct them in a balanced state of supply and demand of the workforce. And, of course, in our country, we need to strengthen an IT information platform for looking for work from the point of view of companies, schools and unemployed.

\section{REFERENCES}

1. Athanasopoulou, A., Moss-Cowan, A., Smets, M., \& Morris, T. (2018). Claiming the corner office: Female CEO careers and implications for leadership development. Human Resource Management, 57(2), 617-639.

2. Dalton, G. W., Thompson, P.H., \& Price, R.L. (1977). The four stages of professional careers: A new look at performance by professionals. Organizational Dynamics, 6(1), 19-42;

3. Raghunathan, D., Vadavi, D., \& Harikiran, A. G. (2017). Development and Validation of Questionnaire to assess the careers chosen by dental graduates: CPAD-Q. International Journal of Innovative Research in Dental Sciences, 2(3), 64-70.

4. De Vos, A., De Hauw, S. D., \& Van der Heijden, B. (2011). Competency development and career success: The mediating role of employability. Journal of Vocational Behavior, 79, 438-447.

5. Erhel, C., Gautie, J., \& Gazier, B. (2015) In Search of a European Employment Strategy: the Construction of the "Job Quality," Université Paris1 Panthéon-Sorbonne (Post-Print and Working Papers)

6. Erikson, E.H. (1950). Childhood and Society. New York: Norton

7. Europe Commision, European Employment Strategy, 2010

8. Greenhaus, J.H. (2008). Career Management. Hinsdale, II: The Dryden Press;

9. Greenhaus, J.H., Callanan, G.A., \& Godshalk, V.M. (2010). Career Management ( $3^{\text {rd }}$ ed.). Fort Worth, TX: Harcourt College Publishers.

10. Hedge, J.W., \& Rineer, J.R. (2017). Improving Career Development Opportunities Through Rigorous Career Pathways Research. RTI Press Publication No. OP-0037-1703. Research Triangle Park, NC: RTI Press. https://doi.org/10.3768/rtipress.2017.op.0037.1703

11. Janevska, I. A., Postolov, K., \& Magdinceva, S.M. (2019). Generational Differences in Achieving Work-Life Balance. MEST Journal DOI 10.12709/mest.07.07.01.02, Fortcoming 
12. Micić, R., \& Arsić, Lj. (2017). Human resources in a sustainable development function [Ljudski resursi u funkciji održivog razvoja], Ekonomski pogledi, 19(2), 31-48.

13. Ministry of labour and social politics, National Strategy of Employment, 2016-2020)

14. Paramita, P.D., \& Warso, M.M. (2016). The influence of development careers and empowerment to the competence of employees through professional work. Journal of Management, 2(2), 1-14.

15. Pulevska, I. L., Postolov, K., Janevska, I.A., \& Magdinceva, S.M. (2017). Establishing Balance Between Professional and Private Life of Generation. Research in Physical Education, Sport and Health, 6(1), 3-9.

16. Schein, E.H. (1987). Individuals and careers. In J.Lorsch (Ed.), Handbook of organizational behavior (pp.155-171). Englewood Cliffs, NJ: Prentice Hall.

17. Tertuliano, I.W., Oliveira, V., Pavlovic, V., \& Machado, A.A. (2018). The need for expatriation and the planning of the process: Organizational looks for sports. Ekonomski pogledi, 20(1), 1-18.

18. Weng, Q., \& McElroy, J.C. (2012). Organizational career growth, affective occupational commitment and turnover intentions. Journal of Vocational Behavior, 80, 256-265.

19. Weng, Q, \& McElroy, J.C. (2016). The Connections Between Careers and Organizations in the New Career Era: Questions Answered, Questions Raised. Journal of Career development, 43(1). 3-10

20. Werner, J.M., Simone, R.L. (2009). Human Resource Development, South-Western, $5^{\mathrm{e}}$

21. https://www.businessballs.com/self-management/eriksonspsychosocial-theory-of-human-development/\#-span-wfd-id-147eight-stages-span- (accessed on 22.03.2019) 